\title{
Teaching Reform of Power Electronic Technology Course of OBE Education Model
}

\author{
Dandan $\mathrm{Ma}^{1, \mathrm{a}^{*}}$, Jing $\mathrm{Bai}^{1, \mathrm{~b}}$ and Ping $\mathrm{Xin}^{1, \mathrm{c}}$ \\ ${ }^{1}$ College of Electrical and Information Engineering, Beihua University, Jilin 132021, China \\ amadandan11@126.com, bjlbyj@163.com, xinping_1107@sohu.com
}

Keywords: Outcomes; Driving force; Teaching reform; Comprehensive assessment

\begin{abstract}
Due to the strong theoretical power electronics course, and in the process of teaching the lack of effective evaluation of students learning effect, It is difficult to achieve the expected teaching goal. This paper in detail discusses the meaning, theoretical basis and characteristic of OBE education model. And it put forward the OBE education model can be introduced in power electronics course. Under OBE the study results is identified as a driving force. It also means "study results- design of teaching process- evaluation system" model, and it would effectively improve the quality of personnel training.
\end{abstract}

\section{The Meaning of OBE Education Model}

In the 1990s, a kind of education model was popular in American. Its name was Outcomes-Based Education, OBE.In the year of 1994, American researcher William G. Spay told the following interpretations of OBE in <Outcome-based education: critical issues and answers> "Each link of the education system should be clearly focused and organized, then determine a learning goal which be centred on can reach planned results upon completion of the learning process[1]." It emphatically point out that learning outcome is the first. It doesn't matter how to study and when to learn. Australia's education sector define OBE as 'It is an education process based on students' specific learning outcomes in which education structure and curriculum be viewed as means rather than aims. If they do not contribute to cultivating student's specific ability, they should be amended. Learning outcomes should driver the operation of the education system[2]."

OBE's advocates consider it could achieve expect goals and talent training at top speed if educators do as following. Define students' talent training goal, take learning effect as purpose, improve education teaching methods, revise education syllabus, enact new theoretical practical teaching project, do education activities whatever can conveniently achieve the training objectives[3-8].

\section{Analysis of Power Electronic Technology Curriculum}

Power electronic technology is the backbone course of Electrical engineering. This cross discipline involves Electronics, Electrical Science and Control Theory. Its important theory is foundation of subsequent courses. Its application is becoming more and more widely. Now in universities' various teaching way they almost give priority to theory and experiment is secondary. Although this indoctrination can initiates pupils into theoretical knowledge, but the learning outcome is not ideal. The traditional education model's means to the evaluation of teaching effect is single one-sided in which students' learning effect can't be totally measured and it can't promote the reform of teaching and learning model. So it can't effectively improve the quality of personnel training also.

At present, power electronics teaching there are following problems:

(1)Conventional teaching and training were based mainly on the transfer of knowledge, but ignored the students' learning effect.

(2) Most of teaching was given priority to theory, but experimental classes were very few. In the fewer experiments, students could only verify some fundamental converter. But most converters could not be verified, much less systematic application. 
(3) Most of Students' learning interest derived from teacher's personality charm and attraction to the examples before learning which caused shortage of learning motive in the subsequent study even giving up learning in the boring abstract theoretical research.

Finally, because teaching attention was focused on the teachers and the teaching process, so students understand the knowledge one-sided superficially. A piece of paper based on teaching content unable evaluates students' learning fully.

To solve above problems, this paper make a reform in many aspects such as teaching content, teaching methods, teaching plan and teaching subjects with the OBE's education model which could fundamentally solve the problems existing in the traditional force-feeding teaching model and improve the learning effect greatly.

\section{The Teaching Reform of Power Electronic Technology Base on OBE}

In OBE model, students are the main part of learning, teaching plan, teaching method and teaching content are all unfolded around the students' learning effect. This is different from traditional way completely. Therefore, we can carry out the reform in the following respects 。

\section{Taking Study Results as a Driving Force Strengthen the Student's Main Body Status}

In OBE model, establish the results as power, results exist before the content. So, tapping the potential teaching resources, limiting study time, making Q\&A is all around the center of students.

Firstly, position expectant learning effect reasonably that to cultivate talent with what ability by teaching. The goal of course contains theoretical depth and practice ability, analysis expression ability, the team cooperation ability.

Secondly, take this goal as a driving force, carry out flexible teaching. In the teaching process, students' interests must be respected. After the students take the initiative to realize the goal of the ego, a sense of accomplishment and worth will inspires them to a higher goal. Ultimately achieve the desired learning effect.

Thirdly, Change the rigid teaching time into a flexible architecture. Using the test before the commencement of the course, check the previous knowledge and experience. Students who pass the test can choose to attend classes according to individual need which eliminate repetitive learning.

\section{Taking Study Results as a Driving Force Optimize Theory Teaching Content}

With the results as the target, first compress basic theory, then according to the actual application establish some special topics which purpose is to stimulate students interest in learning. After determining the learning path, students can select to participate in the topics. Teachers make Q\&A for students as needed. These lectures should be completed jointly by several teachers, special topics' time should be staggered. The advantage is communication between teacher to teacher or teacher to student can promote each other, inspire each other, and make the business level of teachers and students enhancing unceasingly.

At the same time, open teaching resources for example related information about topics, the work from older students, course team's teaching material which has been generalized to the document and web sites. Students can consult these resources at any time. Theory teaching architecture is shown in Table 1.

Teaching plan accordingly be adjust. Assign the compression of fundamental theory class to project and practice. Students could realize the anticipated goals in repeated research between theory, practice and literature. 
Table 1 Theory teaching architecture

\begin{tabular}{|c|c|c|}
\hline Stage & Objective & Time allocation \\
\hline $\begin{array}{l}\text { Basic theory } \\
\text { teaching }\end{array}$ & $\begin{array}{l}\text { To master the main content of } \\
\text { the course. }\end{array}$ & \multirow{2}{*}{$\begin{array}{l}\text { After the preliminary } \\
\text { test, it is available to } \\
\text { arrange the time } \\
\text { practically. There is no } \\
\text { rigid rules. }\end{array}$} \\
\hline $\begin{array}{l}\text { Application } \\
\text { topics }\end{array}$ & $\begin{array}{l}\text { Clear learning objectives, } \\
\text { Make learning route. }\end{array}$ & \\
\hline Q\&A & $\begin{array}{l}\text { To guide the learning methods, } \\
\text { provide learning resources. }\end{array}$ & $\begin{array}{l}\text { Coordinate with the } \\
\text { teacher, hours are not } \\
\text { fixed. }\end{array}$ \\
\hline
\end{tabular}

\section{Taking Study Results as a Driving Force Reinforce Practice Teaching Content}

Firstly, must increase practice session. Complete not only basic theory test and verify but also comprehensive experiments and practice by team. These are completed as plan in fixed time. Secondly, increase the opening intensity of laboratory. To support students for team innovation practice activity with the idea inspired by the project. Laboratory not only provides practice space, experimental apparatus but also guide the specific operation.

Practice is very important, during this process students build self-confidence and sense of worth which will make subsequent innovation practice get twice result with half effort. Practice implementation architecture is shown in Table 2.

Table 2 Practice implementation architecture

\begin{tabular}{|c|c|c|c|}
\hline Stage & Objective & time allocation & $\begin{array}{l}\text { teaching } \\
\text { subject }\end{array}$ \\
\hline $\begin{array}{l}\text { Basic theory } \\
\text { experiment }\end{array}$ & $\begin{array}{l}\text { To deepen understanding the } \\
\text { main points. }\end{array}$ & \multirow{4}{*}{$\begin{array}{l}\text { Take reasonable } \\
\text { arrangement } \\
\text { neatly } \\
\text { according to the } \\
\text { need. There is } \\
\text { no rigid rules. }\end{array}$} & \multirow{2}{*}{ Teachers } \\
\hline $\begin{array}{c}\text { Comprehensive } \\
\text { experiment }\end{array}$ & $\begin{array}{l}\text { To exercise integrated use of } \\
\text { knowledge points. }\end{array}$ & & \\
\hline $\begin{array}{c}\text { Curricular } \\
\text { practical } \\
\text { training }\end{array}$ & $\begin{array}{l}\text { To strengthen the team } \\
\text { cooperation, and Learn to the } \\
\text { integrated use of knowledge. }\end{array}$ & & \multirow{2}{*}{ students } \\
\hline $\begin{array}{l}\text { Innovative } \\
\text { practice }\end{array}$ & $\begin{array}{l}\text { To guide the learning } \\
\text { method, and provide learning } \\
\text { resources. }\end{array}$ & & \\
\hline
\end{tabular}

\section{Taking Study Results as a Driving Force, Establish Comprehensive Evaluation Methods}

Take comprehensive evaluation in more stages and more respects that include the examination results of basic theory, basic experiment and comprehensive experiments' class and report results, Curricular practical training examination results, innovation practice work quality and practicability inspection results and so on. Also, examination should carry out from the theoretical depth and expression ability, the report quality and the maneuverability of the work, etc. Details are shown in Table 3. 
Table 3 comprehensive evaluation architecture

\begin{tabular}{|c|c|c|c|c|}
\hline Stage & $\begin{array}{l}\text { Assessment } \\
\text { form }\end{array}$ & Grades & $\begin{array}{l}\text { Accounts for } \\
\text { proportion of } \\
\text { comprehensive } \\
\text { assessment }\end{array}$ & $\begin{array}{c}\text { Comprehensive } \\
\text { assessment }\end{array}$ \\
\hline Basic theory & test paper & \multirow{5}{*}{$\begin{array}{c}\text { excellent, } \\
\text { good, } \\
\text { medium, pass, } \\
\text { not pass. }\end{array}$} & 0.2 & \multirow{5}{*}{$\begin{array}{c}\text { Pass, } \\
\text { not pass. }\end{array}$} \\
\hline $\begin{array}{c}\text { Basic } \\
\text { Experiments }\end{array}$ & reports & & 0.1 & \\
\hline $\begin{array}{c}\text { Comprehensive } \\
\text { experiments }\end{array}$ & reports & & 0.1 & \\
\hline $\begin{array}{c}\text { Curricular } \\
\text { practical } \\
\text { training }\end{array}$ & $\begin{array}{c}\text { reports }+ \\
\text { assessment }\end{array}$ & & 0.2 & \\
\hline $\begin{array}{l}\text { Innovative } \\
\text { practice }\end{array}$ & $\begin{array}{c}\text { reports + } \\
\text { works + } \\
\text { assessment }\end{array}$ & & 0.4 & \\
\hline
\end{tabular}

\section{Conclusion}

Power electronic technology is one of the most important lessons in Electrical engineering, and has the effect of continuity in the professional personnel training. On the basis of existing reform based on CDIO and excellent engineer education, introduce OBE education concept, so it's easier to carry out and implement the education model which take study results as a driving force. The reform experience of this course will also be the solid foundation to advance reform of OBE in the whole curriculum system.

\section{Acknowledgements}

This paper is supported mostly by the national college students' innovative entrepreneurial training project (201510201011), partially by the Jilin Province department of education Science and Technology Plan Project (Grant NO.201656), partially by the Beihua University undergraduate course excellent teaching team (NO.201635), partially by the Beihua University Education Teaching Research Project (Grant NO.XJYB2016016).

\section{References}

[1] Spady W G. Outcome-based education: critical issues and answers [M]. Arlington: American Association of School Administrators, 1994: 1-10.

[2] Tucker S.E. Literature Review: Outcomes-focused Education in Universities [OB/EL].Learning Support Network, Curtin University of Technology. http://lsn.curtin.edu.au/outcomes/docs/Lit Review.pdf.

[3] Jing Bo. OBE: Outcome-Based Education [J].Studies in Foreign Education. 2003, 30(3): 35-37.

[4] Qiu Jianfeng. The operating system course teaching reform with OBE education model [J].Computer Education.2015, (12):28-34.

[5] Liu Rong. University Course Learning Evalution from the Perspective of OBE Theory[J]. China Education of Light Industry.2016,(1):15-17.

[6] Gu Peihua. OBE Engineering Education Model in Shantou University[J]. Higher engineering education research.2014, (1)27-37. 
[7] Song Yue. Study and practice of construction of Embedded Measurement and Control Technology course group based on OBE[J]. Experimental Technology and Management.2016,2(33):4-10.

[8] Chen Xiaoqian. Constructing Students' Comprehensive Quality Evaluation System Based on OBE Emgineering Education Model [J].Journal of Zhejiang Unicersity of Technology(Social Science).2015,14(4):464-467.

[9] Yang Yigang. A Study on the Technological Innovative Ability Training Based on the OBE Model [J]. Higher engineering education research.2015,(6):24-30.

[10] Xie Qiong. Conception on the Learing Outcomes Evaluation Model of the Hotel Management Generality Course Based on the Outcome-based-education [J].Journal of Education Institute of Jilin Province.2012, 2(28):87-88.

[11] Song Zhigang. Outcome-Based Program Development: A Case Study of OBE Teaching Reform in Northern Alberta Institute of Technology[J]. Journal of Shenzhen Polytechnic.2013, (1):63-65. 